
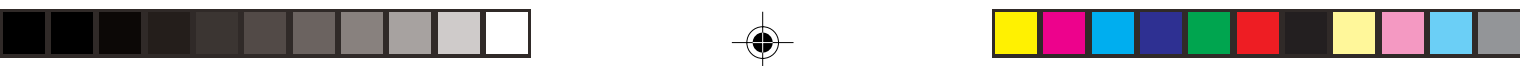

\title{
Enquête: Skiftende illusioner på museet
}

Jeg har hørt om et etnografisk museum i Japan hvor det første man ser i afdelingen om Europa er en stor hestetrukken sigøjnervogn. Det er nok ikke lige dét de fleste europæere ville forestille sig som blikfang i en udstilling om dem selv. Tilsvarende har europæiske etnografiske museer længe beskrevet andre kulturer ved hjælp af genstande der var håndlavede, iøjnefaldende, typiske for deres lokalsamfund og gerne farverige. Ligesom sigøjnernes hestevogn er tingene i mange tilfælde gået ud af brug på det sted de engang kom fra og er blevet erstattet af masseproducerede varer der er ens allevegne. De udstillede museumsgenstande er ofte valgt ret usystematisk over flere perioder og på forskellige lokaliteter efter hvad der med indsamlerens øjne så mest lokalt eller traditionelt ud.

Gennem de sidste par årtier - og sideløbende med repræsentationsdebatten i den teoretiske antropologi - er den traditionelle museumsetnografi blevet kritiseret for således at fremstille andre samfund som eksotiske, uforanderlige og isolerede fra omverdenen. Kritikken er især kommet fra museerne og antropologien selv, som en faglig diskussion om hvorvidt museet skaber en illusion om andre folkeslag der er meget langt fra deres daglige virkelighed.

I forlængelse af kritikken af den eksotiske illusion har museerne - ligesom i universitetsantropologien og andre fag - kastet sig over dekonstruktionen af „Vestens blik på Resten“. Det er der kommet mange spændende udstillinger ud af som fortæller om de mennesker der i tidens løb har samlet genstandene ind til museerne, deres personlige og professionelle årsager til at rejse ud og deres syn på de folk de studerede, koloniserede, handlede med eller missionerede blandt.

Ligesom i den skrevne antropologi kan selvrefleksionen på museet imidlertid blive så omsiggribende at man ikke når længere end til dekonstruktionen af betragterens blik og helt opgiver beskrivelsen af de andre folkeslag og deres verden. Herved kommer man til at fremstille europæernes fortolkning som om den var ganske uafhængig af virkeligheden - en fri opfindelse af „,den Anden“.

Hvis vi for eksempel ser på de skiftende europæiske fremstillinger af kineserne fra 17-tallets glorificerende beskrivelser af de dygtige og vise kinesere til 18-tallets kritik af orientens despotisme og dekadence, så skyldes forandringen ikke blot europæernes tilfældigt skiftende fortolkning. I samme periode svækkes Kinas position som center for verdens $\varnothing$ konomien gradvist med internt forfald af samfundsinstitutioner til følge, mens Europa har sin verdensøkonomiske opkomst og en deraf følgende samfundsmæssig og videnskabelig blomstringstid. Europæernes rejsebeskrivelser 
og de kinesiske genstande de hjembragte i de forskellige perioder er formet af disse ydre betingelser i begge verdensdele.

Kan man få sådanne bredere historiske og etnografiske perspektiver med i en udstilling kan museumsgenstandene fortælle om livet $\mathrm{i}$ andre dele af verden, såvel som om Europas skiftende relationer til disse steder. Hvis man derimod nøjes med at fremstille det europæiske syn på „den Anden“ som en fri fortolkning, ender man med en endnu større illusion end dén om de isolerede og stillestående eksotiske kulturer. Herved reduceres de andre kulturer og deres genstande nemlig til kun at fremstå som objekter for den europæiske indsamler; som om de ikke havde en egen eksistens der var værd at beskrive.

Afslutningsvis kan det tilføjes at sigøjnervognen og de andre gamle ting på museet naturligvis ikke skal fremstilles som om de var hentet i den nutidige oprindelseskultur. De må præsenteres som de historiske objekter deres ofte lange tid på museet har gjort dem til. Selvom det etnografiske museum i sin tid fødtes som et sted for samtidige ikke-europæiske samlinger, så er hovedparten af samlingerne i dag et stykke materielt verdenshistorie. Denne historie fortjener også at blive vist og fortalt - alene eller som historisk baggrund for mere nutidige etnografiske genstandssamlinger.

Bente Wolff

Antropolog, ph.d. Museumsinspektфr 